\title{
Migration as the Way for Better Employment Perspectives: Case of European Union
}

\author{
V. Kumpikaitė Valiūnienè
}

\begin{abstract}
Migration influences changes in labor market among countries. People migrate because of better employment perspectives very often inside of European Union (EU). However, migrants face with challenges to be employed in organizations because of cultural and value differences. Therefore, it is important to find balance between migrants-employees' and organizations' needs matching. This paper presents the main reasons of migration, and statistical analysis of migration situation in EU. Moreover, theoretical approach of employee-organization fit model from point of view of migrants is proposed in this study too. Scientific literature and statistical data and comparative analysis are used to reach the aim of this study.
\end{abstract}

Index Terms-Employee, migration, motives, organization, KSA.

\section{INTRODUCTION}

People have always left their homes in search of better economic opportunities, both within and outside of their own homeland. There are around 200 million people - about three percent of the world's population living in a country not of their birth [1]. Majority of these people are of the working age. Such mobility of labor force influence changes of labor market in different countries as well as situation in organizations.

The topic of migration is not new by itself and is analayzed by many scholars. Migration is a phenomenon that has major societal, regional, national and transnational consequences [2]. However it is still lack organizational - managerial approach. Migration management is one of the major political and humanitarian challenges facing the world in the twenty-first century. Migration and work-based mobility has become more ubiquitous today than ever before [3].

The purpose of this paper is to present migration as the way for better employment perspectives, looking at migrants' and organizations' needs compatibility.

Scientific literature and statistical data and comparative analysis are used to reach the aim of this study.

\section{MigRATION REASONS}

It should be mentioned that migrants and their relationships to host societies and institutions have been studied from many different perspectives (e.g., sociological, psychological, economic and labor perspectives (see Table I))

Manuscript received March 26, 2015; revised May 28, 2015

V. Kumpikaitè Valiūnienè is with Kaunas University of Technology, Economics and Business School, Donelaicio g. 20-401, Kaunas 44239, Lithuania (e-mail: vilmante.kumpikaite@ktu.lt). but still remain understudied by organizational scholars [4]. Moreover, all these studies still lack analysis from sending/home countries context as more and more countries start confronting problems affected by emigration [5].

Motivations for migration vary. Scientific literature gives different classifications of reasons for migration. Identification of migration reasons from the side of Person's dimension could be classified to a certain groups of factors as economic, political, demographic, and geographical. The importance of these various factors is different to every person and can change in time. Usually all factors are divided to demand-pull and supply-push factors (see Fig. 1, Table I).

TABLE I: DIVERSE DISCIPLINES RESEARCHERS' FOCUS ON MIGRATION DECISIONS [6]

\begin{tabular}{|c|c|c|}
\hline Research flied & The main focus & Description \\
\hline Economists & $\begin{array}{l}\text { Pull and push } \\
\text { factors }\end{array}$ & $\begin{array}{l}\text { The reasons leading to migrate } \\
\text { are motivated and sustained by } \\
\text { three major types of influences: } \\
\text { demand-pull factors in the } \\
\text { destination area; supply-push } \\
\text { factors in the origin area; } \\
\text { network factors that link origin } \\
\text { and destination areas. }\end{array}$ \\
\hline Sociologists & $\begin{array}{l}\text { Chain migration } \\
\text { process }\end{array}$ & $\begin{array}{l}\text { Migration begets additional } \\
\text { migration. The first person } \\
\text { emigrating from the area sends } \\
\text { information to those in the home } \\
\text { country about jobs, housing, and } \\
\text { schools in the new setting. }\end{array}$ \\
\hline Anthropologists & $\begin{array}{l}\text { Changes in the } \\
\text { standard of living } \\
\text { and culture }\end{array}$ & $\begin{array}{l}\text { First-hand accounts from new } \\
\text { immigrants as well as media } \\
\text { accounts of the country's } \\
\text { standard of living entice people } \\
\text { to immigrate to the new country } \\
\text { for a better way of life. }\end{array}$ \\
\hline Psychologists & $\begin{array}{l}\text { Personality } \\
\text { factors }\end{array}$ & $\begin{array}{l}\text { Personality factors are important } \\
\text { in the desire to emigrate. Those } \\
\text { who want to resettle in another } \\
\text { country tend to be more } \\
\text { work-oriented and to have higher } \\
\text { achievement and power } \\
\text { motivation, but lower affiliation } \\
\text { motivation and family centrality, } \\
\text { than those who do not want to } \\
\text { leave their country of origin. }\end{array}$ \\
\hline Political scientists & $\begin{array}{l}\text { Ethno political } \\
\text { reasons }\end{array}$ & $\begin{array}{l}\text { Countries may encourage } \\
\text { emigration to ease ethnic } \\
\text { conflict, or to establish presence } \\
\text { in another country, by resettling } \\
\text { particular ethnic groups } \\
\text { voluntarily or involuntarily. }\end{array}$ \\
\hline
\end{tabular}

There is no single factor explaining why the desire of some people to migrate to another country does not become real. Many factors can influence the situation, for example characteristics and personal circumstances of potential migrants, such as their health status, their family or/and financial situation and their job status. In addition, cultural and institutional characteristics such as administrative 
barriers and migration policies in the origin and the desired destination country either encourage migration by keeping costs of migration relatively low, or increase migration costs throw for instance language training requirements, high legal barriers, etc.

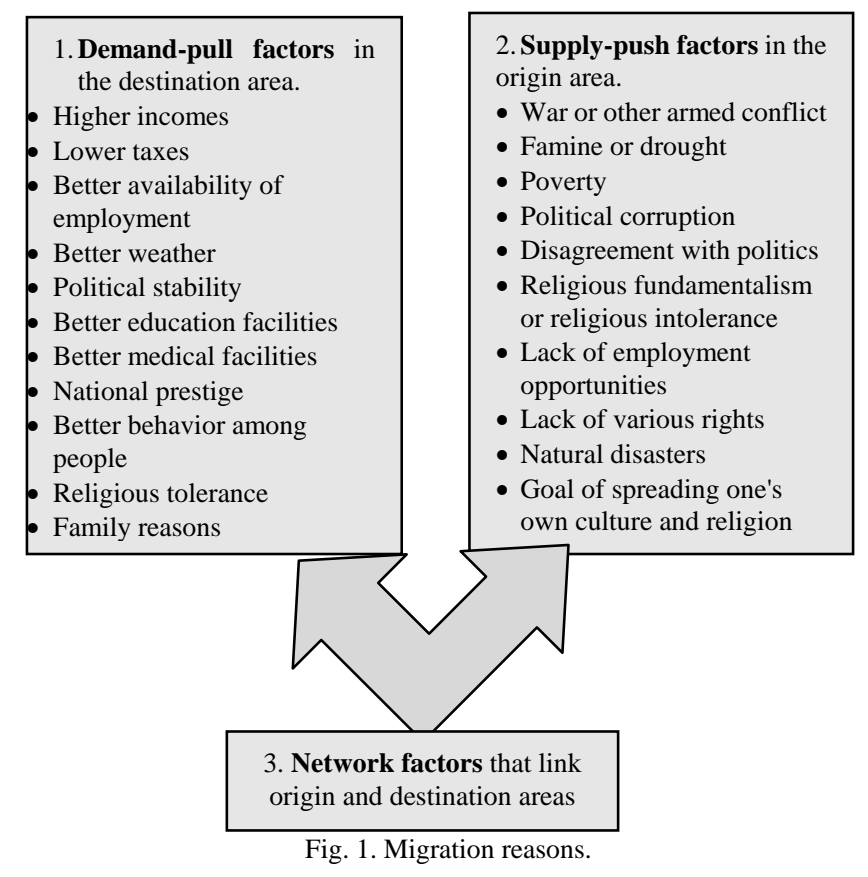

\section{Migration’s SitUATION IN EUROPEAN UNION}

\section{A. Migration Rate}

As [7] presents, Central European countries including Germany, Switzerland, Austria, the Benelux countries, and France have been the most important immigration countries as well as traditionally the port of entry of many labor migrants in Europe. However, since the 1980s, the Southern European countries such as Italy, Greece, Spain, and Portugal have also become immigration countries, receiving people from Northern Africa, the Balkans, and the Eastern Mediterranean, mostly through illegal immigration due to the proximity to these regions, the geographical features. European Union has created one economic and free movement of workers space. It has not only opened the borders providing the opportunity to travel, study, work and live within European Union (EU) for more than 500 million citizens of EU member countries, but also faced the problem areas that require solutions.

The biggest immigration was in Germany (592.2 persons per 1000 citizens), UK (498), Italy (350), France (327.4) and Spain (304.1) in 2012 (Eurostat, 2015). At the same time 5 countries with the lowest immigration are following: Estonia (2.6), Slovakia (5.4), Malta (7.1), Croatia (9.0), and Portugal (14.6). Looking at net migration (see Fig. 2), we can see that negative net migration was the biggest in Lithuania (-23.7 person per 1000 people) in 2010. And this number is huge having in account that Lithuania is one of the smallest countries in EU with around $2.8 \mathrm{mln}$ of population. This negative number decreased till -7.1 in 2012 and is in the second place after Ireland. Among other countries with negative net migration we can see other Baltic countries as
Latvia and Estonia, also Poland, Bulgaria and Cyprus. Comparing situation in 2010 and 2012 it should be mentioned that in Spain, Portugal and Greece net migration from positive in 2010 changed in to negative in 2012. This, undoubtedly, is connected with economic situation in all those countries. We can see interesting situation in Spain, as its immigration was one of the biggest (304.1 persons) and net migration was negative ( -3 persons) in 2012. It means that even Spain is attractive for less developed counties, especially from Africa, at the same time Spanish people emigrate from there. This situation is more analyzed and presented in [9], [10].

\section{B. Minimum Wages}

One of the most important criteria for decision of migration is salary and purchasing standards in different countries. These indicators of EU in 2015 are presented in Fig. 3. The 22 EU Member States that have national minimum wages can be divided into three main groups based on the level in euro. In January 2015, ten Member States had minimum wages below $€ 500$ per month: Bulgaria (€184), Romania (€218), Lithuania (€300), the Czech Republic (€332), Hungary (€333), Latvia (€360), Slovakia (€380), Estonia (€390), Croatia (€396) and Poland (€410). In five other Member States, minimum wages were between $€ 500$ and $€ 1000$ per month: Portugal (€589), Greece (€684), Malta $(€ 720)$, Spain $(€ 757)$ and Slovenia $(€ 791)$. In the remaining seven Member States, minimum wages were well above $€ 1000$ per month: the United Kingdom (€1379), France $(€ 1458)$, Ireland ( $€ 1462)$, Germany ( $€ 1473)$, Belgium and the Netherlands (both $€ 1502$ ) and Luxembourg (€1923). For comparison, the federal minimum wage in the United States was just over $€ 1000$ per month (€1035) in January 2015.

Study [12] in Lithuania showed that such economy indicators as unemployment rate in percent, Gini coefficient and Tax Freedom Day have the biggest influence on emigration.

Due to increased opportunities of labor market mobility organizations are able to search for the most competent and suitable employees, but, at the same time, actual or potential employees use opportunities to move within the EU.

\section{Migrants' Diasporas}

Immigrants creates strong Diasporas. Members of a diaspora can be migrants themselves or migrants' children or grandchildren not born abroad. Some of these persons hold the nationality of their country of residence; others have more than one nationality and still others only that of the country where they currently reside. The potential contribution of a diaspora to the economic and social development of its country of origin will depend on many factors, such as its size, average skill level, wealth, seniority and degree of organization. It will also depend on the prevailing conditions in the country of origin and on the institutional support the diaspora receives. For example Turks' diasporas in Germany (21.6\% of country population), Austria $(11,4 \%)$, Polish in Iceland (43.7), Ireland (22.1), and Norway (16.8\%), Brazils' in Portugal (25.3\%), Ukrainians' in Czech Republic (25.5\%) and Poland $(23.6 \%)$, Indians' in UK $(7.2 \%)$, Romanians' in Hungary (24\%) and Spain (15\%) and Moroccans' in Spain 
(15\%) [13]. Table II presents 4 countries where immigration was the biggest in 2012 and a number of foreigners there in percent per 1000 of citizens. France is not included in to this table as data by individual country is not available there.

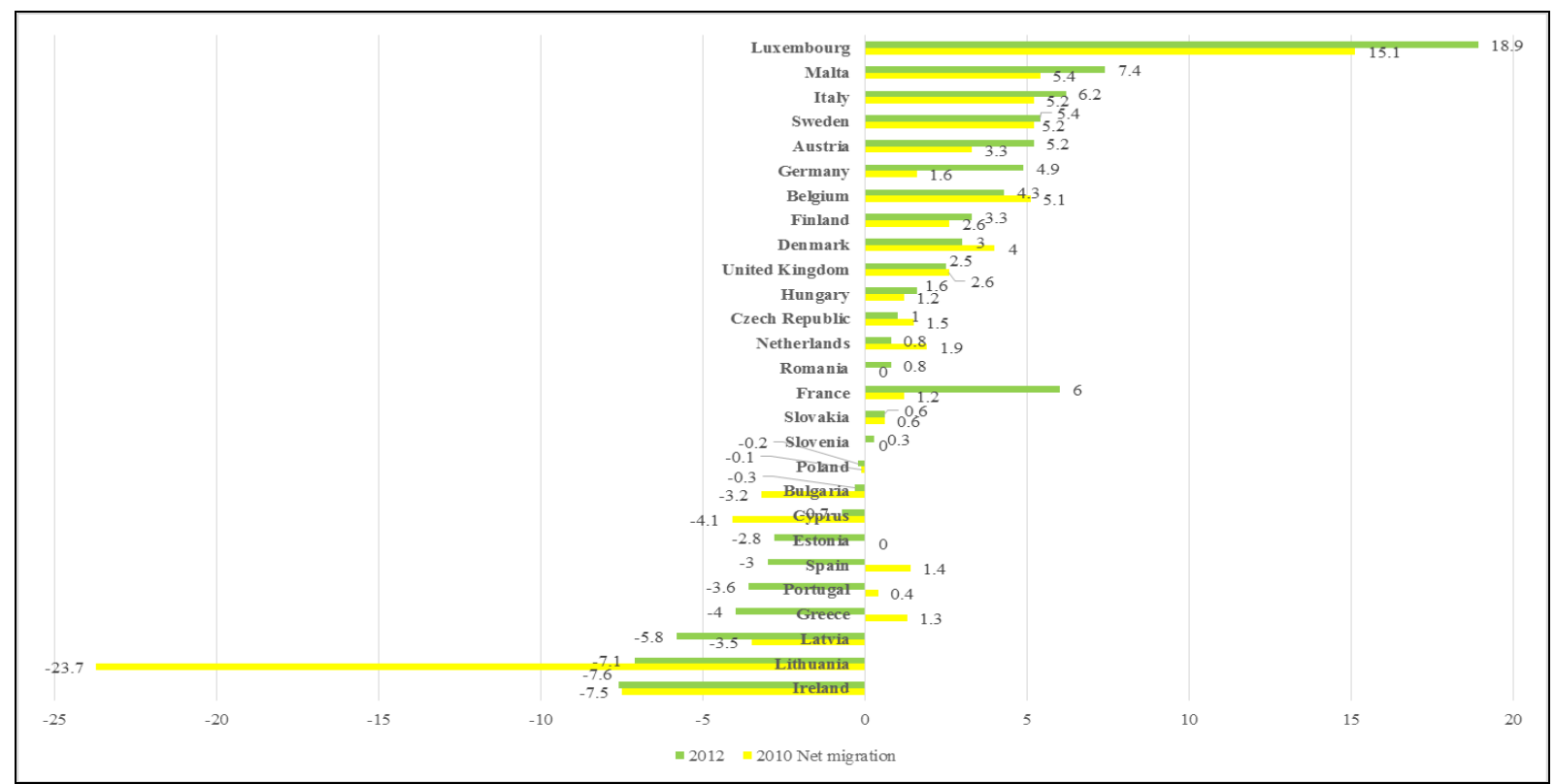

Fig. 2. Net migration in EU in 2010 and 2012 (persons per 1000 citizen) [8].

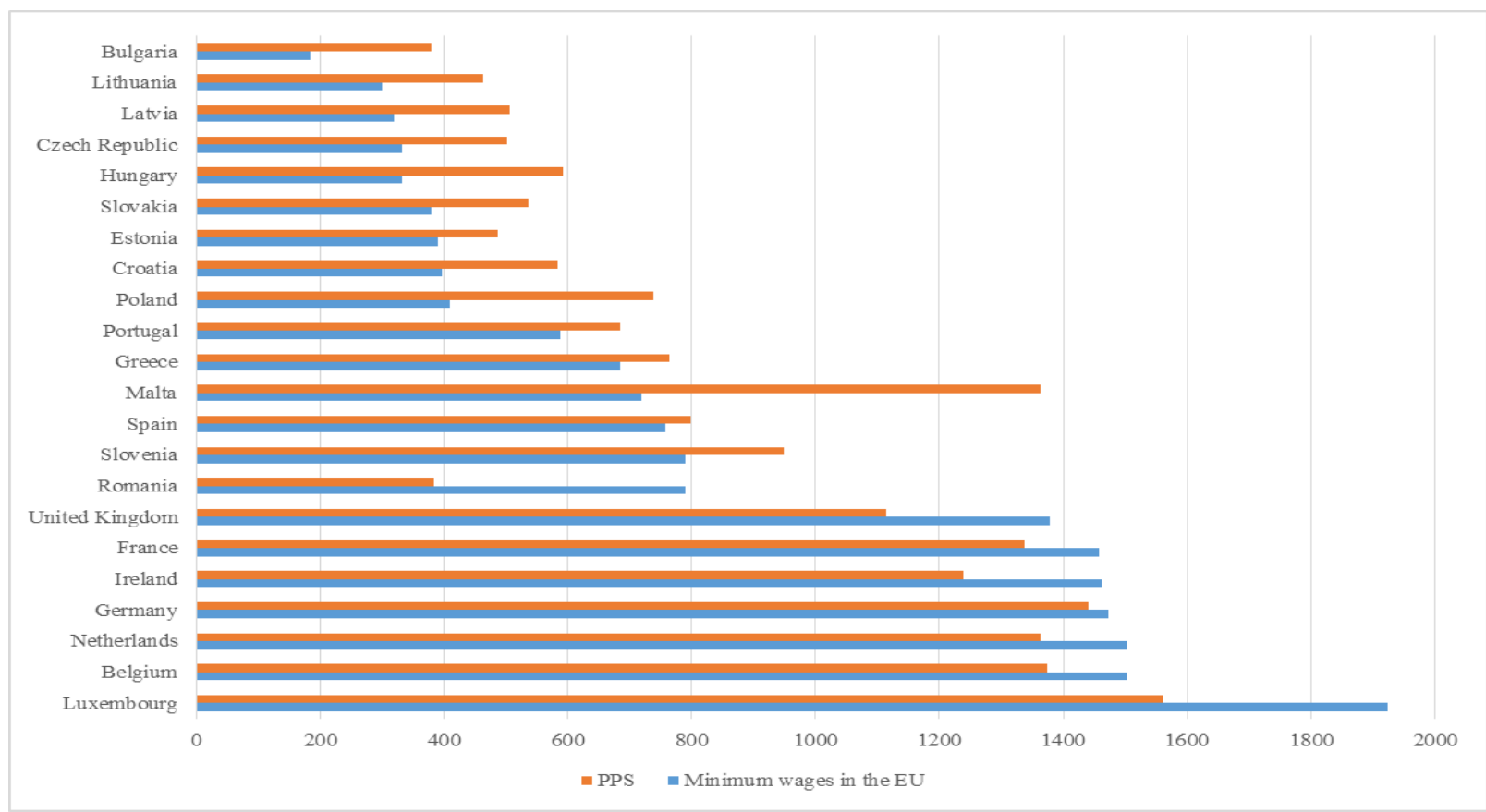

* PPS 2015 are estimated

Fig. 3. Minimum wages per month and minimum wages per month in estimated purchasing power standards (PPS) in the EU,1st January 2015 [11]

TABLE II: MIGRANTS DIASPORAS IN PERCENT IN FOUR EU COUNTRIES WITH HIGHER IMMIGRATION IN 2012 [13]

\begin{tabular}{|c|c|c|c|c|c|c|c|}
\hline \multicolumn{2}{|c|}{ Germany } & \multicolumn{2}{|l|}{ UK } & \multicolumn{2}{|l|}{ Italy } & \multicolumn{2}{|c|}{ Spain } \\
\hline Citizens of & $\%$ & $\begin{array}{l}\text { Citizens } \\
\text { of }\end{array}$ & $\%$ & $\begin{array}{l}\text { Citizens } \\
\text { of }\end{array}$ & $\%$ & $\begin{array}{l}\text { Citizens } \\
\text { of }\end{array}$ & $\%$ \\
\hline Turkey & 21.6 & India & 7.2 & Romania & 21.7 & Romania & 15.2 \\
\hline Poland & 7.4 & Ireland & 6.5 & Albania & 10 & Morocco & 15 \\
\hline Italy & 7.4 & Pakistan & 3.7 & Morocco & 9.4 & UK & 6.2 \\
\hline Greace & 4.1 & $\begin{array}{l}\text { United } \\
\text { States } \\
\end{array}$ & 3.4 & China & 4.9 & Equador & 5.3 \\
\hline Croatia & 3.1 & Lithuania & 2.9 & Ukraine & 4.4 & Columbia & 4.4 \\
\hline Others & 56.5 & Others & 76.2 & Others & 49.7 & Others & 53.9 \\
\hline
\end{tabular}

\section{Foreign Citizens and Self-employment in Europe}

With migrants eager to undertake this work, firms and the economy grow as productivity increases and inflationary pressures reduce. And idea that a foreign population has a positive effect on new business formation is propose by other researches also [14]. Migrant workers also add large levels of entrepreneurship and self-employment, thereby creating new jobs for the country workforce. This can act as a spur to local people to start their own business, giving further impetus to economic growth [15]. In general, immigrants are more likely to be self-employed than similarly skilled native-born workers, while self-employment rates of immigrants exceed in many countries those of native-born. 
In comparison countries with the biggest numbers of foreign-born workers in self-employment were Poland (29.2\%), Austria (18.8\%), Hungary (16.4), Italy (17.5\%), and Belgium $(15.5 \%)$. It is common tendency that foreign-born people are more like to be self-employed. However we can see opposite situation in Greece, Italy, Ireland, Portugal, Spain, Germany and Slovakia. As we can see from Table III, differences in Slovakia and Germany are very small when those differences are almost $16 \%$ in Greece, around 7\% in Italy and Ireland. The reasons of situation should be analyzed in more details, however the authors of this paper suppose that mentioned Southern countries face huge illegal immigration from Africa.

In comparison countries with the biggest numbers of foreign-born workers in self-employment (see Table III) were in Poland (29.2\%), Czech Republic (15\%), Austria (18.8\%), Hungary (16.4), Italy (17.5\%), and Belgium $(15.5 \%)$. It is common tendency that foreign-born people are more like to be self-employed. However we can see opposite situation in Greece, Italy, Ireland, Portugal, Spain, Germany and Slovakia. Differences in Slovakia and Germany are very small when those differences are almost $16 \%$ in Greece, around $7 \%$ in Italy and Ireland. The reasons of situation should be analyzed in more details, however, it could be supposed that mentioned Southern countries face huge illegal immigration from Africa.

According to [16] for high-skilled immigrants and for immigrants from countries where skills are less readily transferable to the host. In the case of high-skill immigrants, there is more room to drop down the occupational ladder when migrating and more scope for upward mobility following migration, relative to less-skilled immigrants. In the case of immigrants from countries with very different labour markets, the move from one country to another is more likely to involve downward mobility, but, as with high skilled immigrants, as location-specific human capital is acquired, upward mobility is possible.

\section{TABLE III: FOREIGN CITIZENS AND SELF-EMPLOYMENT IN EUROPE}

\begin{tabular}{lllll} 
Countries & $\begin{array}{l}\text { Total } \\
\text { immigrants } \\
\text { per 1000 }\end{array}$ & $\begin{array}{l}\text { Foreign } \\
\text { citizens } \\
\text { in } \%,\end{array}$ & $\begin{array}{l}\text { Native workers } \\
\text { in self- } \\
\text { employment, } \%,\end{array}$ & $\begin{array}{l}\text { Foreign-b } \\
\text { orn } \\
\text { workers in }\end{array}$ \\
& $2012 *$ & & $2009^{* *}$ & self- \\
& & & employme \\
& & & nt, $\%$, \\
& & & $2009 * *$ \\
\hline
\end{tabular}

\begin{tabular}{lllll}
\hline Austria & 91.6 & 11.2 & 9.3 & 18.8 \\
\hline Belgium & 147.4 & 11 & 12.1 & 15.5 \\
\hline Croatia & 9 & 0.6 & - & - \\
\hline Denmark & 54.4 & 6.4 & 7 & 9.6 \\
\hline Estonia & 2.6 & 15.7 & - & - \\
\hline Finland & 31.3 & 3.4 & 9.6 & 14.1 \\
\hline France & 327.4 & 5.9 & 8.1 & 10.8 \\
\hline Germany & 592.2 & 9.1 & 10 & 9.5 \\
\hline
\end{tabular}

\begin{tabular}{|c|c|c|c|c|}
\hline Greece & 110.1 & 8.6 & 26.4 & 10.6 \\
\hline Hungary & 33.7 & 2.1 & 10.8 & 16.4 \\
\hline Ireland & 54.4 & 10.6 & 16.8 & 9.3 \\
\hline Italy & 350.8 & 7.9 & 23.6 & 17.5 \\
\hline Lithuania & 19.8 & 0.7 & - & - \\
\hline Luxembourg & 20.5 & 43.8 & 5.4 & 6.5 \\
\hline Netherlands & 124.6 & 4.2 & 11 & 11 \\
\hline Poland & 217.5 & 0.1 & 11.2 & 29.2 \\
\hline Portugal & 14.6 & 4.2 & 15.6 & 12.1 \\
\hline Romania & 167.3 & 0.2 & - & - \\
\hline Slovakia & 5.4 & 1.3 & 12.6 & 12.1 \\
\hline Slovenia & 15 & 4.2 & - & - \\
\hline Spain & 304.1 & 12 & 16 & 11.7 \\
\hline Sweden & 103.1 & 6.8 & 8.5 & 10 \\
\hline $\begin{array}{l}\text { United } \\
\text { Kingdom }\end{array}$ & 498 & 7.6 & 11.9 & 13.4 \\
\hline
\end{tabular}

$*[8], * *[17]$.

\section{EMPLOYEE-ORGANIZATION FIT MODEL}

Of course, not all emigrants are self - employed. As we see from Table III self-employment's percent varies from 6.5\% In Luxembourg till $29.2 \%$ in Poland for foreigners at the same time from $6.4 \%$ again in Luxembourg till $26 \%$ in Greece for native citizens. One of the reasons migrants become entrepreneurs is it is easier than to satisfy organizations' needs.

Thinking about migrants' involvement to work in organization it is possible to use idea for combining people and organizations [18]. He proposed that people and organizations could be combined in three ways:

1) The first way is to provide by one side what the other one needs.

2) The second way describes the situation when both people and organizations share similar fundamental characteristics.

3) The third way involves both previous.

In this study it was selected the 1st way and the model was developed in regard of the fit of person's and organization's needs.

In each description both sides as the organization (employer) and the employee have expectations and needs. Sometimes these expectations match. The problems occur when the expectations do not match. In case of migrants it could be because of cultural and values differences, language barriers, etc. Therefore it is important to explore these expectations.

Employees' job performance, employees' behavior in 
general, is a function of what they know, what they are able to do and what they believe. It is proposed criteria which indicates that a person's performance depends on the interaction of motivation, their knowledge, skills and attitudes (KSA), and environment [19]. If people do not have the KSAs, they cannot perform. [20] mentioned knowledge (professional, practical, operational), skills and spirit as expectations for employees. Competencies represent learning outcomes and are assessed by companies through their HR frameworks that are usually evaluating employability skills, capabilities and key competencies [21]. Motivation depends on employees. Environment refers to the physical surroundings in which performance must occur, including barriers and aids to performance, as well as objects and events that people might see as indicating that employees' performance will be rewarded or punished. Therefore, organization could wish from employees' good performance, having good KSA and being motivated.

Speaking about person-organization fit model, it should be in account needs and expectations, which organisations have from their employees and migrants' needs and expectations from organization. Conceptual of such balance model is proposed in Fig. 4.

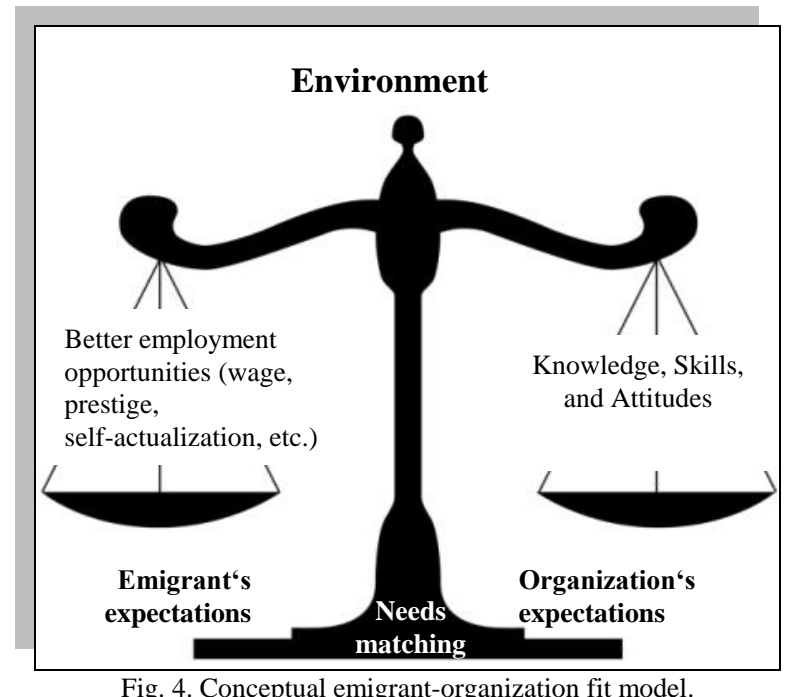

Each of the factors motivation, KSA, and environment can influence performance, but it is the combination of these factors that determines the person's performance. It helps us to understand whether poor job performance is due to KSAs or other factors. The likelihood of engaging in any activity, then, is limited by the weakest factor. For instance, no matter how knowledgeable or skilled a person is, if he is not motivated to perform the activity - or worse, is motivated not to perform it - then he will not.

\section{CONCLUSION}

Changing situation in world economics and on labor market influence importance and strength of pull and push factors, which make the biggest impact on decision to migrate. One of the most important factors are better employment possibilities with better wages.

Statistical analysis of migration rates and wages in EU showed that minimum wages differ from $€ 184$ in Bulgaria up to $€ 1923$ in Luxembourg. This is one of the migration reasons and influence immigration to countries with high wages (the biggest net migration rate is in Luxembourg) and emigration from countries with low wages as Bulgaria, Latvia, and Lithuania.

It is common that imigrants work as self-employed more than local people. It is because not just of large migrants' Diasporas in those countries but also of not matching expectations with employer's because of cultural differences, and not understandable expectations.

Therefore this paper proposes theoretical model of employees (migrants) and employers (organization) expectations matching, including KSA and needs of employees.

As future work of developing this study is to answer the questions: "What main problems do organizations face because of migration? How organizations and migrants could satisfy and match their expectations?"

\section{REFERENCES}

[1] Centre for Global Development, Migration Details. (2008). [Online]. Available:

http://www.cgdev.org/section/initiatives/_active/cdi/_components/mig ration

[2] A. Otoiu, E. Titan, and R. Dumitrescu, "Internal and international migration: Is a dichotomous approach justified?" Procedia - Social and Behavioral Sciences, 2014, vol. 109, pp. 1011-1015.

[3] Entrepreneurship and Migrants. Report by the OECD Working Party on SMEs and Entrepreneurship. [Online]. Available: http://www.oecd.org/cfe/smes/45068866.pdf.

[4] S. Binggeli, J. Dietz, and F. Krings, "Immigrants: A forgotten minority," Industrial and Organizational Psychology: Perspectives on Science and Practice, vol. 6, no. 1, pp. 107-113, 2013.

[5] V. Kumpikaite and A. Ramirez, "Reasons of students' emigration: comparison analysis of Lithuania and Spain," Vadybos mokslas ir studijos - kaimo verslų ir jų infrastruktūros plètrai : mokslo darbai = Management theory and studies for rural business and infrastructure development: Research papers, Kaunas, Akademija: ASU Leidybos centras, 2013 , vol. 35 , no. 3 , pp. 398-404

[6] R. Čiarnienė and V. Kumpikaitè, "International labour migration: students viewpoint," Inžineriné Ekonomika = Engineering Economics, vol. 22, no. 5, pp. 527-533, 2011.

[7] T. Baycan-Levent and P. Nijkamp, "Characteristics of migrant entrepreneurship in Europe," Entrepreneurship \& Regional Development, Special Issue: Regional Science Perspectives on Entrepreneurship and Regional Development, vol. 21, no. 4, pp. 375-397, 2009.

[8] EUROSTAT. [Online]. Available: http://ec.europa.eu/.

[9] A. Mihi-Ramírez, A. Rudžionis, and V. Kumpikaitè-Valiūnienè. "European economic migration flow, earnings and unemployment in decade of 2000," Procedia - Social and Behavioral Sciences, vol. 110, pp. 122-129, 2014

[10] A. M. R. Antonio and V. Kumpikaite. "The whys and wherefores of student international migration: European and Latin-American economic perspective," Economics and management = Ekonomika ir vadyba, no. 18, pp. 351-359, 2013.

[11] Monthly minimum wages in euro varied by 1 to 10 across the EU in January 2015. [Online]. Available: http://ec.europa.eu/

[12] V. Kumpikaitė and I. Žičkutè, "Regression analysis of economic factors influencing emigration rate in Lithuania," Procedia - Social and Behavioral Sciences, vol. 92, pp. 457-461, 2013.

[13] Ec. Europa. (2014). Migration and migrant population statistics. [Online]. Available: http://ec.europa.eu/

[14] B. A. Kirchhoff, S. L Newbert, I. Hasan, and C. Armington, "The influence of university R\&D on new business formations and employment growth," Entrepreneurship Theory and Practice, vol. 31, pp. 543-559, 2007.

[15] International Labour Migration. A UNISON Discussion Paper. 2004. [Online]. Available: http://www.unison.org.uk/file/a2444.pdf.pdf

[16] B. R. Chiswick, Y. L. Lee and P. Miller, "Longitudinal analysis of immigrant occupational mobility: A test of the immigrant integration 
hypothesis," International Migration Review, vol. 39, pp. 332-333, 2005.

[17] International Migration Outlook 2009. [Online]. Available: http://www.oecd.org/migration/mig/internationalmigrationoutlook200 9.htm.

[18] A. E. Kristof, "Person-organization fit: An integrative review of its conceptualization, measurement, and implications," Personnel Psychology, vol. 49, pp. 1-49, 1996.

[19] P. N. Blanchard and J. W. Thacker, Effective Training, Systems, Strategies, and Practices, International Edition, Pearson Prentice Hall, Pearson Education, Inc., 2004.

[20] B. D. Ictenbas and H. Eryilmaz, "Linking employers' expectations with teaching methods: Quality function deployment approach," Procedia Social and Behavioral Sciences, vol. 28, pp. 568-572, 2011.

[21] C. Chiru, G. Ciuchete, G. G. Lefter (Sztruten), and E. Paduretu (Sandor), "A cross country study on university graduates key competencies. An employer's perspective," Procedia - Social and Behavioral Sciences, vol. 46, pp. 4258-4262, 2012.

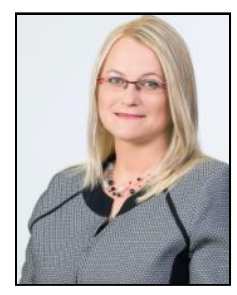

Vilmante Kumpikaite Valiuniene was born in Lithuanian in 1975. She gained the bachelor's degree in personnel management in 1997, the master's degree in quality management in 1999 and the $\mathrm{PhD}$ in management and administration in 2004 (all at Kaunas University of Technology, Lithuania). Her major field of studies is emigration's reasons.

She is a professor of the Department of Management and a head of International Migration Research Center of Economics and Business School at Kaunas University of Technology, Lithuania. She worked as an engineer and a consultant in "Telebaltikos konsultacija" in Kaunas (Lithuania) in 1998-2002 and a director of educational international company "Cet Baltica" in 2006-2010. She is an author and coauthor of more than 60 scientific publications. Her research interests include international migration, intercultural differences, human resource training and development, modern learning/teaching methods and moral values in business.

Prof. Vilmante Kumpikaite Valiuniene is a member of International Economics Development and Research Center (IERDC), Academy of Management (AOM), European Academy of Management (EURAM), European Group for Organizational Studies (EGOS) and scientific and organizing committee of EURAM 2011, ICM21 conferences. 